\title{
CELEBRATION OF JOHN MARSHALL DAY IN CONNECTICUT.
}

\author{
FEBRUARY 4, 1901, IN HENDRIE HALL, YALE LAW SCHOOL.
}

OPENING REMARKS BY DEAN FRANCIS WAYLAND.

It would seem almost an impertinence, before an audience of lawyers, lawyers in praesenti et in futuro, if I should remind you that in the year 1899, at its annual session, the American Bar Association recommended the celebration of this day as the hundredth anniversary of the inauguration of John Marshall as Chief Justice of the Supreme Court of the United States. And, by the way, it may interest us to recall the fact that his immediate predecessor in this high office was Oliver Ellsworth, of Connecticut.

The Bar Association also recommended the observance of this day by Congress, by the Supreme Court of the United States, by the Bar Associations of the different States, by Law Schools, and other educational institutions. Our own celebration combines the Law Department of Yale University and the State Bar Association, represented on this platform by its President, the orator of the day, and His Excellency, the Governor of the State. The Federal Judiciary is represented by Judge Shipman of the Circuit Court and our own Judge Townsend of the District Court; Yale University has manifested its cordial interest in the occasion by the attendance of President Hadley and a large number of the Faculty of the University.

It will be gratifying to you all to know that we have with us, as an honored and welcome guest, a grand-niece of the great Chief Justice. Two telegrams of to-day will interest you. The first one is addressed to Judge Baldwin in his capacity as the Mentor of the Law School and the recent President of the American Bar Association. [Applizuse and cheers.] 
"Illinois sends greeting to Connecticut and American Bench and Bar united in one American brotherhond on this bistoric day.

[Signed]

"Apolph Moses,

$\left\{\begin{array}{l}\text { "Chairman Associated Committee, } \\ \text { of Lllinois for John Marshall Day." }\end{array}\right.$

To Mr. Moses, a prominent member of the bar of Chicago, is due the credit of having originated this idea. The replyis as follows :

"Connecticut and Yale return salutation of Illinois. All honor to Marshall from our Universities, for he attended at William and Mary the first University law course given in America, and from our States, for he made their foundation sure.

[Signed]

[Applause.]

"FRANCIS WAYLAND, "Dean of the Yale Law School; "SnEON E. BAIDWIN, I. Member of National Committee

Perhaps there will be no better opportunity for me to correct an error which appeared in one of our local journals this morning. It was stated that John Marshall was graduated at the Yale Law School. Now we are quite willing to grasp at any honor which is fairly within our reach, but that is a little beyond; as John Marshall studied law in 1779 in William and Mary, taking, as Judge Baldwin says, the first course of lectures there. As we were born some time in 1824, there seems to be a slight, not to say a palpable incongruity.

And now it is my pleasant duty to call the commander-inchief to the front. I have the honor to introduce His Excellency the Governor, who has kindly consented to act as our presiding officer. [Long-continued applause and cheers.]

INTRODUCTORY ADDRESS BY HIS EXCELLENCY THE GOVERNOR OF CONNECTICUT.

Gentlemen: I see I am down for an introductory address; this is not according to the agreement, and I presume that is why the good Dean, in the kindness of his heart, has made an excellent introductory address preceding me.

There are one or two thoughts, however, and only one or two, that perhaps might precede the treat that is to follow. I do not agree with McCullom or Sarah Dobney or Herbert that the mill will never grind again with the water that is past; the lines fascinate in their hopelessness only; they are not true; the 
mill may grind again and again with the water that is ever journeying from sky to earth and from earth to sky. And I do not agree with Shakespeare that it is the evil rather than the good that men do that lives after them. When a great man loves and labors and passes by the living his life returns ever to help and elevate succeeding generations, and the influence of that life gathers rather than loses energy with the years. Washington is dearer and Lincoln comes closer to the hearts of the people with every passing February; and we, to-day, have met to welcome, with renewed interest, the spirit of the man who stood with Washington and Hamilton and kept the bridge so valiantly in the brave days of old; defended and saved the Constitution from the assaults of error and envy, and laid the base of the pyramid of the great Union in stuff that can never be moved or broken; and it is with pleasure that I am here with you to listen to the life of this great man, and with pleasure that. I have first to introduce to you the President of the University, who needs no introduction to this audience. [Long-continued applause and cheers.]

ADDRESS OF WELCOME BY PRESIDENT HADLEY.

Ladies and Gentlemen: It is a matter of happy omen that the opening of the new Law School Building should come on a day so historic as this, and be graced by an assemblage so rep. resentative of all that is best in the State of Connecticut.

In behalf of Yale University I welcome the Law School on coming fully into its own. In behalf of Yale University and the Law School alike I welcome those members of the Bar of the State, present and prospective, and those whose interest in the best work that is done on legal lines has brought them here.

We did not arrange the weather of the day, nor did John Marshall; and yet, it is not without significance that to this audience is given an opportunity to prove that they care as little for the storms of adversity, in the weather or in a higher sense, as did John Marshall himself, and it also has this advantage, that we see so great enthusiasm for the work for which he stands that had it not been for the weather I doubt whether our hall could have held the numbers that would have thronged to it.

But you are not here to listen to words such as you can hear every day. It gives me great pleasure to make way for a 
better, for a man whose orations always bring to hear him those who enjoy good, straightforward thinking, well expressed, and brought home to all the hearts and consciences of mankind. [Long-continued applause and cheers.]

GOVERNOR M'LEAN.

I now have the pleasure of introducing to you the President of the Connecticut Bar Association, Charles E. Perkins, who will tell us all about the great Chief Justice. [Applause.]

\section{JOHN MARSHALL.}

AN ORATION DELIVERED BY HON. CHARLES E. PERKINS, PRBgIDENT OF THE STATE BAR ASSOCIATION.

One hundred years ago to-day, John Marshall, of Virginia, for the first time took his seat as Chief Justice of the Supreme Court of the United States. To-day, throughout this country, meetings are being held in honor of his appointment, attended by the most eminent men; and there is a general feeling among the educated classes of our people, that the occasion is one that ought to be celebrated, and kept in remembrance. There is something unusual about this. Such commemorations are usually confined to great generals, or great statesmen, such as Washington, Grant or Lincoln ; men who have performed great deeds which have been the salvation of the nation, have made it what it is, or preserved it from destruction; why, then, should Marshall's appointment be so celebrated? It is because it is largely through him that these United States have become a Nation.

Marshall was by no means unknown in 1801. Born in Virginia in 1755, he entered the army of the Revolution at the age of twenty, became a captain in 1777 , and remained in that position until February, 1781. During this time he took an active part in the battles of the Brandywine, Germantown, and Monmouth, besides a number of smaller engagements. In 1781, he commenced the practice of law, at first in his native county of Fauquier, and afterwards at Richmond. In 1782, he was elected to the Legislature of Virginia, and was often re-elected until 1797. In 1796, he was offered the position of Attorney-General of the United States by Washington, and in 
the same year was solicited to accept the mission to France, both of which positions he declined. In 1797, however, President Adams persuaded him to accept the latter appointment with General Pinckney, and Elbridge Gerry, and he returned from France in 1798. At the urgent solicitation of Washington, he consented to become a candidate for Congress, and was elected in 1799. Shortly before this he had been offered the position of an Associate Justice of the United States Supreme Court in the place of Mr. Justice Iredell, who had resigned, but he declined the appointment. At the close of the session he was nominated by Adams for Secretary of War, but this nomination was withdrawn, and his name again sent to the Senate for Secretary of State, which position he accepted, and occupied until January, 1801, when his name was sent to the Senate for its approval of his nomination as Chief Justice of the Supreme Court; the appointment was unanimously confirmed, and one hundred years ago to-day he took his seat on the bench.

It appears, then, that he was no unknown man, or one only of local fame, but of national reputation; and he was worthy of it. Commencing the practice of his profession in 1781, at the age of twenty-six, in 1801, at the age of forty-six, after only twenty years' practice, he stood confessedly first at the bar of Virginia, then one of the ablest in the country, against such competitors as Patrick Henry, Campbell, Lee, and Randolph, and certainfy among the first of the lawyers of the whole country. For years he was employed on one side or the other, in every important case in his State.

There was then so little business before the Supreme Court of the United States, that from 1790 to 1796 , only ten cases are reported. In the latter year, Marshall made his first appearance before that tribunal, as leading counsel in the celebrated case of Ware, administrator, v. Hylton and others. In that case the defendants had owed a debt to a citizen of Great Britain, which, under the laws of Virginia, had been sequestrated and paid to the State. By the treaty between the United States and Great Britain it was provided that creditors of either nation should meet with no lawful impediment to the recovery of debts; and the question arose whether the terms of the treaty could annul the laws of a State. The case was of vast importance, involving new, intricate and difficult questions, and was argued by the ablest men in the country, but it was said, by contemporary observers, that the argument of Marshall was of such astonishing force and extraordinary 
ability as to raise him at once to the highest eminence of professional fame. He was not an orator in the usual meaning of that word. He indulged in no flights of fancy, or mere graces of speech; but for complete grasp of a complex and difficult subject, clearness of thought, lucidity of expression, and power of reasoning, he seems to have been surpassed by no lawyer of those or later times.

Still, great as he was, as a lawyer and a judge, ability in either respect would not have placed him in the position he now occupies, if it had not been for the circumstances in which he came to the bench, and the effect of his views and decisions upon the life of the nation. It was his construction of the Constitution of the United States, and the effect of his decisions, that made us a nation.

That Constitution is the most remarkable document that ever came from the minds of men. There had been republics and democracies before, and federations of various kinds; but in no other country, so far as I know, had there been a definite, written Constitution by which they were governed. Even the Constitution of England, about which we have heard so much, is chiefly remarkable from the fact that it exists only in theory, and really has no binding force on the law-making power. But the problem which presented itself to the men of 1787 was not merely to frame a method of governing and administering one republic; that would have been comparatively easy; but here were thirteen distinct States or political organizations, each of which was as separate from the other, so far as influence or power over each other was concerned, as England is from France; differing in manners and customs, in views and opinions, more or less jealous of each other, and unwilling to lose their individual rights and authority.

These thirteen distinct sovereignties were to be so combined as to form one nation which was to be sovereign for certain purposes, and yet leave the States sovereign for all other purposes, and it was necessary for the convention to decide what powers should be reserved by the States, and what delegated by them to the new nation. This would have been difficult enough if the members of the convention had been broad-minded, intelligent, unprejudiced men, met together with no prepossessions, to determine on principle what would be best to do; for there were absolutely no precedents in history or experience to guide them; but this was by no means the case. The people in every State were divided into two parties, 
the principal difference between them being this very question of what should be the relative powers of these respective governments. The Federalists, headed by Hamilton, desired to have a single nation of great power, almost like England; and to reduce the powers of the States as much as possible. The opposition, afterward called the Republican party, headed by Jefferson, and including many other men of great ability and strong and honest beliefs, desired to limit the power of the new government as much as possible, and to keep as much power in the States as they possibly could. Both these parties were largely represented in the convention by their best men.

The difficulty was, therefore, to frame a Constitution which would satisfy all reasonable men of both parties, and be accepted by all the States, and yet would give to the new government such powers as were needed to make it of real benefit. It hardly seems possible that this could ever have been done, but it was done, and so well done, that although made for only thirteen States, and a few millions of people, it has been found adequate and sufficient for forty-five States and over seventy millions of people; and it is even greater proof of the wisdom and foresight of these men, that with the exception of the ten amendments passed in 1791, and which have always been regarded as practically part of the Constitution itself, only two amendments, each of minor importance, were made until after the convulsions of the Civil War.

Neither of the two great parties was able to carry out its wishes in full; in some instances compromises weremade; and the result was to bring about in many cases the use of broad general expressions which might be construed in different ways, rather than minute detailed provisions. All the people, however, had learned from bitter experience, during the Revolution, that a mere federation of the States without some power above them all, would be insufficient; and the Constitution and the ten amendments were finally adopted.

This, however, did not change the views and desires of the two great parties : the contest was only remored to a new field. It still became necessary to determine what the words used in the Constitution meant, and how it was to be interpreted. Those who had fought the battle for State sovereignty in the convention were still as ready and anxious to urge that the new government should have no powers that had not been clearly and expressly given to it, and that the expressions used should be so construed as to be restrained within the narrow- 
est limits. The controversy was only removed from the Conrention to another forum.

It was obvious that a mere written constitution, without some absolute authority to interpret it and decide what its meaning really was in relation to many intricate and embarrassing questions and to enforce its decisions, would be useless, and therefore some such authority must be provided. The most unique and remarkable feature in this instrument is the provision that the Supreme Court should be a tribunal which should decide all questions arising under it, finally and absolutely, so as to bind both the States themselves and the United States; and having its decisions enforced, if necessary, by the whole power of the government. It was, I believe, the first instance of such a tribunal in all the history of civilized institutions. It is clear, too, that this makes the Judiciary by far the greatest and most powerful of the three departments into which the powers of government were divided. It has the power to determine the validity of all legislation, both of Congress and of the States, and to determine the powers and duties of the Executive; for it has the power to say what the words used in the Constitution and laws actually mean. The power of saying what words mean is greater than the power of selecting and phrasing the words; for it is the ideas which the words convey, and not the words themselves, which are important. To paraphrase a well known saying, "Let who will make the laws if I can construe them." This power is still greater in the case of a Constitution like ours, where of necessity, as well as for reasons already suggested, the expressions are broad and general, instead of detailed and definite.

It is the greatest possible tribute to the wisdom, and respect for law, of the people of the United States, that although the Court has often exercised its great power, and has held many laws passed by Congress as well as by the States, to be void, laws often of great importance, involving great interests, and affecting the feelings and views of large sections of the Union, its decisions have invariably been submitted to; not indeed without objection and disapproval, for that would be too much to expect of human nature, but without defiance and resistance.

This power in the Court made the views of its members of the highest importance. They could so construe the words of the Constitution as to limit and restrain it within the nar- 
rowest bounds, or so as to expand and enlarge it, almost at will. To those of us who believe in a superintending Providence, it may be considered providential that John Marshall, at this crisis, was placed at the head of the Court.

Nor was this a mere theoretical division of opinion between the two great parties; it was a vital and practical one. In the words of Marshall himself, in his life of Washington, the country "was divided into two great political parties, the one of which contemplated America as a nation, and labored incessantly to invest the Federal head with powers competent to the preservation of the Union. The other attached itself to the State government, viewed all the powers of Congress with jealousy, and assented reluctantly to measures which would enable the head to act in any respect independently of the members." This feeling was shown very strongly in the convention which framed the Constitution. Charles Pinckney, of South Carolina, introduced a draft of a constitution commencing, "We the people of the States of New Hampshire, Massachusetts," etc., enumerating all the thirteen States. If a Chief Justice imbued with the latter opinions had been in Marshall's place, the history of the United States would have been very different. Fortunately for us, John Marshall's views on this great question were so clear and strong as to fill his whole nature. As a soldier he had gone through that winter of starvation and frost at Valley Forge, where the disputes between the States composing the confederation were such, that the strongest appeals of Washington could not induce them to agree as to raising even money enough to warm, clothe, and feed the soldiers who were giving their lives for their protection. He had seen and felt the incompetency of that body, and when elected a member of the Virginia Convention called to consider the adoption of the new Constitution, he urged its adoption with such porrer of argument and strength of reasoning, that though opposed by many of the ablest men in the State, among them Patrick Henry, he convinced the convention and secured its adoption.

With these convictions John Marshall assumed the position of Chief Justice and began that series of decisions which has placed him at least as high as any judge in any country. It is difficult for us now to imagine the difficulties of a judge in his position in the United States in 1801. To-day, with the thousands of volumes of American reports, text-books, digests, and other publications, he is either a poor or a lazy lawyer who 
cannot find some authority, in his faror, upon almost any question. But then the case was very different. At the time of Marshall's appointment there were just five volumes of American reports, Kirby and the first volume of Root in Connecticut, and three volumes of Dallas in Pennsylvania, none of which were published by authority of law. There were a number of English reports, but very many of the decisions were not adapted to our circumstances and institutions, and none of them binding on our courts. It was necessary to decide cases as they arose upon reason and general principles of law. While this was true of all legal questions, it was especially so when the Court came to construe the Constitution. Not only were there no precedents, no decisions to aid, but there never could have been any, for no such instrument ever existed, nor any like it. The rules for its construction, and the construction itself, were to be found only in the minds of the Judges; and the foundations and grounds of the decisions had to be based upon reason and sound sense. They must be so reasoned out and clearly expressed as to commend themselves to and convince the minds, not only of the bar, but of the people generally; and especially of those who bad been strongly opposed to the adoption of the Constitution, and were desirous of limiting the powers of the government and of its courts to the utmost extent possible.

In view of the history of this nation, it is almost impossible for us to realize the fears and apprehensions of many men of ability and influence at that time. They seriously believed that there was danger of the absolute destruction of liberty and of State governments, and the establishment of a despotism worse than that of England had ever been. Even Patrick Henry declared that "unless some miraculous erent happened the nation could not retain its liberty," and that the new gorernment "would destroy the State governments, and swallow the liberties of the people"; and many others of great ability and fame agreed with him.

Yet, so strong was the reasoning, so unanswerable the deductions, and so clearly expressed were Marshall's decisions, that they seem to have convinced not only the people generally, but even those most opposed to his viewr. One of the first and all-important questions which arose, was as to the power of the Supreme Court to decide, that laws either of Congress or of the States contrary to any provision of the Constitution were invalid. It will be noticed that no such power is directly 
given to that Court. The Constitution only says, that the judicial power shall extend to all cases arising under this Constitution, the laws of the United States, and treaties.

In 1803, this question arose in the suit of one Marbury against James Madison as Secretary of State, to oblige him to deliver a commission which had been signed. It was brought under an act of Congress authorizing the Supreme Court to issue a mandamus to persons holding office under the United States. The Constitution limited the original jurisdiction of the Supreme Court to cases affecting ambassadors, ministers, and consuls, and those where a State was a party, and the first question that arose was, whether Congress could extend this power; and if it attempted to do so, whether such an act would be valid. John Marshall declared that the people of the United States had formed a government for all of them, and had made the Constitution the supreme law of the whole country; and it could only be altered by the people who made it. It either limited the powers of Congress and of the States, or it did not. If it did, then any act repugnant to it was void; if it did not, then a written Constitution was only an absurd attempt to limit powers in their nature illimitable, and was waste paper. If then such an act was void, he asks, does it, notwithstanding its invalidity, bind the courts, and oblige them to say that although it is not a law, and is absolutely roid, it is to be enforced by courts as if it were a valid law.

This was only a brief summary of the grounds of the decision; they are elaborated in the opinion, and stated in such a lucid, convincing, and powerful manner that no one has ever attempted to question them. This opinion is a good specimen of his powers of reasoning, no oratory, no flights of fancy, no long balancing of arguments pro and con. No one can deny his premises, and his conclusions are so evident that it seems absurd to question them.

In this celebrated case Marshall declares the principle which lies at the foundation of his decisions upon the construction of the Constitution, and which is more fully stated in later cases, namely, that the United States is a nation, created by all the people of the United States acting together as one body; that the Constitution is declared by all the people to be the supreme law of all of them; that the will of the people is supreme and must be obeyed, and consequently no law can exist or be made by any legislative body which is contrary to its provisions. 
It is in this sense that we may say that Marshall was the creator of the nation, and deserves to be celebrated among those who have deserved well of their country; and it is largely for this reason that we here, as well as others elsewhere, are fully justified in commemorating John Marshall's Day.

I do not forget that there were other members of the Court who should share in this praise. Marshall was but one of the six members who at that time formed the Supreme Court; but so great was his power and influence, so convincing his riews and arguments, that his opinions were almost invariably adopted by all. From his pen came almost all the decisions on constitutional questions during his time, and there is but one case, that of Ogden v. Saunders, where a majority, four out of the seven who then composed the Court, disagreed with him, and that was only on one point which was not decisive of the case.

It would take a volume to give even a brief account of all of Marshall's opinions relating to the Constitution, and I shall not attempt to do so. Even a complete summary of the principal questions decided would be beyond my limits. During the thirty-five years that he filled the position of Chief Justice, almost every important question which could arise upon the construction of the Constitution was not only decided, but the decisions were based upon such sound reasoning that they have never been attacked. Some of the most important of these questions may be referred to. Among them were the power to regulatecommerce between the States, and the power of the States over foreign commerce; how far the prohibition to the States of emitting bills of credit extended; the nature and obligation of contracts, and how far the States might affect them; the power in the States to tax creations of the Federal government; the power of the States over Federal officers; the power of the Supreme Court to revise the laws of the States, or the judgments of the State courts; and many others.

In all of these it must be remembered that then there were no precedents, no rules of decision to follow. They must all be reasoned out by the powers of the mind alone, and in the ability to do this Marshall was pre-eminent; in my opinion above any other judge who ever lived. He has sometimes been called the Mansfield of America, but I believe that even Lord Mansfield, the most distinguished of English judges, if placed in Marshall's position, could not have filled it so well. There 
may have been other men who could have done what Marshall did; it is enough for us to say, that no one else ever did. He fully and thoroughly believed that the whole people of the country intended by the Constitution to form a government of the whole country which would be supreme in the powers given to it, and in the authority to enforce them; which would represent the people of a nation, be accountable to them alone, and represent their sovereignty; and it was no more to be unduly limited in the exercise of its proper powers than to be unduly extended beyond them. With this foundation principle in his mind he studied the instrument as a whole, not in isolated parts, interpreting each provision by others so as to make a perfect and uniform system. His principles of construction are admirably and concisely stated by himself in a leading case: "To say that the intention of the instrument must prevail; that this intention must be collected from its words; that its words are to be understood in the sense in which they are generally used by those for whom the instrument was intended; that its provisions are neither to be restricted into insignificance, nor extended to objects not comprehended in them nor contemplated by its framers, is to repeat what has already been said more at large, and is all that can be necessary."

Nor must we forget that while Marshall was resolved to extend the power of the nation to its proper limits, he was as careful not to extend it beyond those limits. His desires on this point are very clearly shown in the celebrated case of McCulloch v. Maryland, the question in which was the right of the State of Maryland to tax a branch of the United States Bank, a corporation created by Congress as a part of the financial administration of the government. The case was especially interesting as the United States claimed that the tax law of the State was invalid as contrary to the Constitution, and the State claimed that the Act of Congress creating the bank was invalid, as beyond the powers given to Congress. In his opinion, Marshall first discusses the last point. He admitted that the Constitution gave no express power to create a bank, in terms, but held that it existed as a part of the power "to make all laws that shall be necessary and proper to carry into execution the powers given to the Government," saying "Let the end be legitimate, let it be within the scope of the Constitution, and all means which are appropriate, which are plainly adapted to that end, which are not prohibited but 
consist with the letter and spirit of the Constitution, are constitutional."

This, I believe, is the furthest extent to which Marshall ever carried the doctrine of powrers not directly given by the Constitution, but only to be implied from it. That doctrine, first enunciated by him, has been questioned by those who may be called strict constructionists, and Marshall has been criticized and accused of unduly and improperly extending the powers of government. Of course, such a principle, like most others, may be carried to too great an extent. It will appear, however, to any unprejudiced observer of Marshall's opinions, and of the reasoning by which he establishes the doctrine, that it is an absolutely necessary one, without which not only the operations of the government would be seriously embarrassed, but almost destroyed. In the final analysis it will be seen that the real objection has always been to the application of the principle to particular instances, rather than to the principle itself.

Upon the other question in the case, it having been once established that the bank was a necessary and proper instrument to carry on the financial operations of the government, the want of power in the States to tax it, was clear. That power, if it existed, might be carried so far as to destroy, which would be inconsistent with the power to create. Nowhere is Marshall's sound judgment better shown than in the manner in which he avoided both too broad and too narrow a construction of the Constitution. At the time of his appointment, one party believed that he would extend the power of the government to the extent desired by the most ardent Federalists; and on the other hand so reasonable a Federalist as Wolcott of Connecticut said that Marshall "would construe the Constitution like a penal statute." That he disappointed both his friends and his opponents, and laid down principles of construction which have been approved and followed down to the present day, is the highest possible compliment to his sagacity.

But although it is his opinions on constitutional questions that have given Marshall his greatest fame, yet he showed no less ability as a judge upon all questions which arose in his time. It is wonderful to see how after a practice of only twenty years at the bar before coming to the bench, questions arising in admiralty law, commercial law, land law, international law, every kind of question which could come before 
the Court, were considered by him, and decided with a power of reasoning, a knowledge of authorities, and a clearness of expression which alone would have given him rank among the highest judges of the world. In many of these cases also, especially admiralty and prize cases, and cases arising under the embargo and non-intercourse acts, new questions continually arose for which there were no precedents, and in which it became necessary to determine broad general principles, and apply them to new and complicated facts, and sometimes to create the law itself. Many of the most difficult and important opinions on these subjects came from his pen, and where they were from those of others, the method of argument shows traces of the influence of his mind.

He showed the same ability in trying cases while holding sessions of the Circuit Courts. It appears that he had serious doubts as to the power of Congress to provide that Justices of the Supreme Court should be required to act as Judges of the Circuit Courts, but yielded his opinion to the views of the other justices and the practice before he was appointed.

The most important case in which he sat at the circuit was the celebrated prosecution of Aaron Burr for treason, and here he showed not only his ability, but his courage and independence in asserting and maintaining the power of the courts, and withstanding public sentiment. This appears in his decision upon the memorable motion made by Burr's counsel for a subpona duces tecum, addressed to Jefferson, then President, ordering him to produce upon the trial a letter written to him by Colonel Wilkinson. Jefferson, who had a high opinion both of himself and his office, indignant at being treated like an ordinary witness, instructed the United States Attorney-General to resist the motion, and intimated very strongly that the Court had no power to call upon him to bring state papers before it, and moreover that if the Court should do so he would not obey.

It was a difficult position, for as the Court was a United States Court, only the authorities of the United States could be called upon to enforce its order, and they were completely in Jefferson's hands; but Marshall was equal to the occasion. He declared it to be his duty to issue the subpœna without regard to consequences, and so firm was he that Jefferson at last yielded, and sent the letter to the Attorney-General to be produced if necessary. 
The same independence was shown in his rulings upon the trial. Whatever may be believed of Burr's real motives and objects, there was a strong feeling throughout the entire community that he was conspiring against the integrity of the Union. Jefferson firmly so believed, and all the power and influence which the government could command was exerted to obtain Burr's conviction. Curiously enough the whole case turned upon the question of the admissibility of evidence. The. overt act of treason alleged in the indictment was the levying of war against the United States at Blennerhassett's Island in the Ohio River. The prosecution having offered evidence to prove acts of other persons at the island, which it was claimed constituted levying war, then proposed to connect Burr with the transaction by collateral testimony, while admitting that he was not in fact present. This evidence was objected to as not admissible under the indictment, and it was seen at once that the whole case turned upon the admissibility of this evidence. Probably no question of evidence was ever argued so thoroughly and at such length. The discussion lasted a whole week; all of the eight able lawyers employed on the case were heard at full length, and the abstract of arguments, with the opinion of the Court, occupies sixty printed pages of the report of the trial. In an elaborate opinion the Chief Justice declared the evidence inadmissible. That ended the prosecution, and the next day the jury, under the charge of the Court, acquitted Burr.

In the language of Wirt, one of the counsel for the prosecution, "Marshall has stepped in between Burr and death." Nor was this decision made without full knowledge of the public feeling on the subject, which was more than hinted at by counsel, but the suggestion was met by words which may well be commended to the consideration of every judge. "That this Court dares not usurp power," said he in his charge to the jury, "is most true. That this Court dares not shrink from its duty is also true. No man is desirous of becoming the peculiar subject of calumny. No man, might he let the bitter cup pass from him without self-reproach, would drain it to the bottom. But if he have no choice in the case, if there be no alternative presented to him but a dereliction of duty or the opprobrium of those who are denominated the world, he merits the contempt as well as the indignation of his country, who can hesitate which to embrace." 
The disappointment of the country at the result of the trial was great, and criticism upon the decision was severe, but Marshall was unmoved. He believed he had done his duty as a judge and was content to await the verdict of posterity, which has been, that no State trial has ever been conducted with more impartial regard for the State, and for the prisoner.

Sitting alone in the Circuit Courts, his finest qualities were perhaps more clearly shown than at the head of the Supreme Court. His serene dignity, which imposed respect on all, his patience in listening, his comprehension of every point made, the accuracy of his rulings, and the clearness and correctriess of his charges to the jury, made him as nearly a perfect judge as it is possible for a mere mortal man to be.

I have thus briefly, and most inadequately, touched upon the judicial career of this great man, which covered so many years and involved so much labor. His decisions, if printed together, would fill thirty or more volumes, and for reasons I have referred to, required more time, thought, and labor, than opinions generally do. Amid all this labor he found time to prepare a most complete and accurate life of Washington, which he afterward revised for a second edition, besides preparing an edition for the use of schools. Washington had bequeathed all his papers, public and prirate, to his nephew, Bushrod Washington, one of Marshall's associate justices, and this great mass of material had to be carefully collated and examined. It was done with a carefulness and accuracy which could not be excelled by one who devoted his whole time to the work. His impartiality and desire to do complete justice is shown as much in this book as in his judicial opinions. $\mathrm{He}$ was a most intimate friend of Washington, on his side in all the conflicts and intrigues which so beset him, and shared his griefs and troubles; yet his statements in relation to them, and to the men whom both Washington and himself distrusted and opposed, were marked by extreme candor and fairness. No tinge of bitterness or personal feeling is apparent, though the facts were such as would well excuse it.

In 1829, at the age of seventy-five, Marshall allowed himself to be made a member of the convention then called to revise the Constitution of his native State, and attended its meetings. It was a scene of great excitement, as both the members of the convention, and the people of the State generally, were not only divided in opinion, but intensely excited. 
The two great questions were: the basis of representation, and the tenure of the judges; and so high did feelings rise that personal collisions occurred in the convention itself, and threats were made of revolution. Never was the influence of one man over an assemblage greater, or more clearly shown. His great ability and experience, his absolute sincerity and truthfulness, his kindness and gentleness of manner and expression were such, that his opinions and advice were regarded with reverence and respect, as almost more than human. His own opinions were decided, and expressed with his usual power, but with the kindest disposition toward those who differed with him, and a desire, if possible, to harmonize conflicting opinions.

He expressed most strongly his views on the subject of the tenure of judges; a matter with which his experience and observation made him more familiar than any one living, and I wish that his opinions on that subject might be read and heeded by all who have the power to pass upon that question. The proposed constitution provided that judges should hold their offices during good behavior, as the former one did, but on one occasion theretofore this clause had been nullified by repealing the laws relating to judges, and re-enacting them, so as to legislate the judges out of office. Marshall proposed a clause which should prevent this evasion of the rule in future, and spoke in favor of it, and of the principle of judicial independence, with all the force of his nature. He said: "The argument of the gentleman goes to prove not only that there is no such thing as judicial independence, but that there ought to be no such thing; that it is unwise and improvident to make the tenure of the judges' office to continue during good behavior." "Advert, sir, to the duties of a judge. He has to pass between the government and the man whom that government is prosecuting; between the most powerful individual in the community, and the poorest and most unpopular. It is of the last importance that in the performance of these duties, he should observe the utmost fairness. Need I press the necessity of this? Does not every man feel that his own personal security and the security of his property, depends upon that fairness? The judicial department comes home in its effects to every man's fireside; it passes on his property, his reputation, his life, his all. Is it not to the last degree important that he should be perfectly and completely independent, with nothing to control him but God and his conscience." "I have always thought from my earliest youth till now, that the greatest 
scourge an angry Heaven ever inflicted upon an ungrateful and a sinning people, was an ignorant, a corrupt, or a dependent judiciary."

Those of us who have had the most experience will feel most strongly the force of these words, and in these days of proposed constitutional changes they are worthy of especial consideration.

As a man, Marshall appears to have been as near perfection in disposition, habits, and conduct, as it is possible for a mortal man to be. It is the universal testimony that from youth to his death he was one of the kindest and most warm-hearted of men. His honor and integrity were without the slightest stain. He had no vices, and I may almost say, no weaknesses. In spite of his eminent talents, his high positions, and his great reputation, there was no tinge of conceit or trace of assumption. His family relations were all marked by the utmost kindness and affection. His charities were constant and great. He bore no malice toward those who offended or injured him. He was a sincere Christian and believed in and obeyed the commands of the Bible.

So, loving and beloved, he reached his eightieth year at the session of the Court in 1835, somewhat feeble in body, but with no weakening of his intellectual vigor. He was so fearful that he might become somewhat incompetent without knowing it, that he often urged his most intimate friends to inform him of the first signs of any mental failure, with the utmost frankness. He presided throughout this term with his accustomed composure and dignity, and his opinions filed in cases then argued show his habitual power and clearness of expression. He returned home at the end of the session, and in May was attacked by a serious illness. He partially recovered from this, but had a relapse in June, and was taken to Philadelphia to obtain the best medical treatment. It was of no avail; and on the 6th day of July, 1835, he left this world for a better.

The death of Marshall touched the feelings of the whole great nation for which he had done so much, and which, in a sense, owed its existence, as a nation, to him. Throughout the country meetings were held, not only by the Bar, but by the public, and the ablest men in the country pronounced eulogies upon his character. Among them we find the names of Webster, Kent, Story, Binney, Sargeant, and many others. They were unanimous in their respect for his abilities and great services, and all expressed the greatest admiration and love for the man. 
One of the most striking passages I find in one of the resolutions of the Bar of Charleston, South Carolina, of all the States the one most opposed to Marshall's opinions as to the proper construction of the Constitution. It is as follows: "Though his authority as Chief Justice of the United States was protracted far beyond the ordinary term of public life, no man dared covet his place or express a wish to see it filled by another. Even the spirit of party respected the unsullied purity of the Judge; and the fame of the Chief Justice has justified the wisdom of the Constitution, and reconciled the jealousy of freedom to the independence of the judiciary."

A study of the character and life of Marshall would be beneficial to any one as an example to be followed, but to none so much as to those who have just been, or are about to be, admitted to the Bar. It does not come to all of us to be judges, nor to those who are judges, whatever may be their talents, does the opportunity come to rival Marshall's great fame. But every one of us may hold him up before us as an example, and feel that the nearer we can conform our lives and conduct to his, the nearer we shall come to the highest perfection of the man, the lawyer, and the judge. [Long-continued applause and cheers.]

\section{GOVERNOR M'LEAN.}

I think I may safely assume the privilege in behalf of every one present to extend to the orator of the day a unanimous vote of thanks for his accurate, exhaustive and charming presentation of his subject. [Applause.] I now have the pleasure of introducing to you the John Marshall of Connecticut, Honorable Simeon E. Baldwin. [Long-continued applause and cheers.]

ADDRESS BY HONORABLE SIMEON E. BALDWIN.

Mr. President and Gentlemen: There is something very impressive in this gathering. The Bar of Connecticut is here, but it is not simply a gathering of the Bar. The State is here in the presence of His Excellency, the Governor, but it is not simply a gathering in the name of the State, for you meet within the walls of the great University of Connecticut, which is yet more than the University of Connecticut. Here she has her home, but where, where are the bounds of the influence 
of Yale? [Great applause and cheers.] And why is it that the University on this occasion here in Connecticut, and at Harvard also, meets the Bar and the State to celebrate this day?

There are two reasons; first, that the University, the modern University in America, makes, as a large part of her life work, the teaching of political science, and that all thoughtful students of political science have come to feel that, in governments under written constitutions like ours, the safety of the State depends upon the intelligence and the firmness of the judiciary, and John Marshall stands, more than any other man, for the judiciary of America.

And another thing: we owe it to Jefferson that the first University course in law offered in America was given at William and Mary College during the hot days of the Revolution. It was-in 1779 , as has been said by the Dean, that Jefferson, revolutionizing the curriculum of William and Mary, striking out chairs he deemed superfluous, brought in the chair of the law of nature and the law of nations and municipal law, and appointed to fill it one of the greatest judges whom Virginia has ever produced, Chancellor Wythe, a signer of the Declaration of Independence.

Marshall, as has been said, was then an officer in the Continental Army. He had begun the study of law at eighteen. He had pursued it for a year or two in a country office, then entered the army, and during a lull in the Revolution, came to William and Mary to be one of this first class under Chancellor Wythe. The country owes a great debt to Wythe and to Jefferson for having given this young law student the opportunity of learning, not only the municipal law of Virginia, which almost any one could teach, but the law of nature and of nations, which few could teach, but which Wythe could.

Much has been said and justly said in the press as this celebration drew on, and has been said to-day, of Marshall as a constitutional lawyer. I am not sure but his work for American law was even greater as a judge, in shaping, what to us was to be accepted as international law. The number of causes involving constitutional points decided while Marshall was on the Bench was about sixty. The number of causes turning on points of international law decided during the same period was over one hundred, and they were important questions and serious questions.

The judiciary of a country like ours, where the judiciary is independent of the Executive, is a great power in making for 
war or in making for peace, with respect to its power to decide questions of international meaning; prize cases; cases such as the Behring Sea controversy recently called forth. Marshall's maiden opinion was one turning on international law, in the case of the Amelia, delivered at the August term of the Court in 1801. At least three doubtful points of international law, involving the rights of neutrals, came before him in that case, and the decision gave form and precision where form and precision before had been wanting. And that was but the first, as I have said, of a long line. I might weary you with speaking of the points that Marshall made clear which before were not, in the field of the laws of nations; but let me say this: the highest court in England, not many years ago, having occasion to consider the rights of a foreign sovereign as to property coming on English soil, said that any student, any judge, who had occasion to investigate that question, must go first to the opinion of Chief Justice Marshall of the United States, in the case of the Exchange.

Marshall, then, won his spurs as a judge, not simply as a constitutional lawyer but as an international lawyer.

And now let me say another thing with reference to why this University may welcome and celebrate this day. It has been the tradition of this University in organizing its Law Department not to shut its doors against those who are not college graduates. If John Marshall were to come to-day to some law schools in the United States, as he was at twentyfour, he could not enter, because he was not a college graduate.

The College can do much for a man. The College can lift, broaden, inspire, but it cannot create the native faculty. After all, the native faculty, that is in the man, is the real title to permanent and lasting success.

And so I say Marshall came to William and Mary as to a university, untrained by college, undisciplined by college life; but well disciplined by patient reading, by deep thought, by participation in the school of life during those stirring days of the Revolution. By the camp-fires of Valley Forge, in the watches of the night, in quiet thought, in solitary meditation he had educated himself; and the man that does that and does it well has done more for himself than even a college could.

Mention has been made of the contest between Marshall and Jefferson in the case of Burr. Jefferson was no friend to Marshall, and yet he was his best friend, for it was Jefferson, as I have said, who, by revolutionizing the curriculum of Wil- 
liam and Mary, made it possible for Marshall to study into the real foundations of the law; it was Jefferson in that way who made possible Marshall's great career, a career called great not only by Americans, but wherever international law is known and respected. [Long-continued applause and cheers.]

GOVERNOR M'LEAN.

Gentlemen: I will next introduce a lawyer and a judge who would make a good Chief Justice of the United States, and who has proceeded further on the road in that direction than any other lawyer in Connecticut, Honorable Nathaniel Shipman of the Circuit Court of Appeals of the United States. [Great applause.]

ADDRESS BY HON. N. SHIPMAN, ILL.D., OF THE CIRCUIT COURT OF THE UNITED STATES.

Mr. Chairman, Dean Wayland, Mr. President, and Brethren of the Bar of Connecticut:

The analyses, by Mr. Perkins and by Judge Baldwin of the constitutional law of this country, which Judge Marshall created, and his contribution to the international law of the civilized world, leave nothing to be said upon those subjects.

In the development of the system of common law, and of equity, which our ancestors brought with thein from their English homes, and to which they adhered with respect, and sometimes with reverence, the Chief Justice was forcibly logical, and forever instructive. Not to go into details, the trial of Aaron Burr, to which Mr. Perkins has alluded, is a classic never equalled and not yet approached. The unerring self-control by which the presiding judge mentally rose above the mists and miasma of popular excitement, and the clearness of judgment which fastened upon and grappled with the central fact of the case were never more perfectly exhibited than in the trial of Colonel Burr; and upon that trial alone Marshall's reputation as a great judge could safely rest.

There are two things which I want to say about Justice Marshall's judicial career, and neither of them has the merit of novelty, for I suppose that each one will be said at least ten times in each meeting in the forty-eight States to-day. The first is this: 
after studying his opinions, and before reading either his biographies or any essays upon his character, every student from 1801 to the present moment has been struck by the singular simplicity and clearness of statement, and by the naturalness of the argument of the great Chief Justice. As the student advances from sentence to sentence, he says to himself, "Of course that proposition is true and is self-evident; I could have thought that, and I could have said it," until, when he has finished, and has taken in the massive force and power of the linked and completed argument, then he says, "This is, as an exhibition of mental strength, incomparable."

The second thing is Judge Marshall's insight into the nature of our dual system of government, and his foresight of the dangers from lax theories in regard to the supremacy of the Federal government in its own realm.

One of his successors on the Bench, Judge Daniel, also from Virginia, who, as Justice Brown has told us, wrote eighty-four opinions and dissented a hundred and eleven times during the nineteen years that he occupied the position, generally spoke of the communities now constituting the States of the Confederacy, and described the Federal government as a creature or agent of the States.

In the mind of Judge Marshall, who, I think somebody has said, was a priceless legacy of the dying Federalist party to the country, and who understood and appreciated and abhorred the idea of a Confederacy, these theories of the Judge Daniel class condemned the country to perpetual weakness and impotence.

The present working, efficient capacity of the Constitution, the strength of the power and dignity which the Federal government now possesses, are due to Marshall's wisdom and foresight. If a man of narrow theories, or of weak courage, had been Chief Justice when Cohen v. Virginia was decided, the country would have been a petty, third-rate power, with not much more pigor and capability of expansion than it had under the Articles of Confederation. Marshall's comprehension of the powers of the Federal government averted helpless paralysis, and enabled Justice Bradley to declare, in the Siebold case, that the government of the United States may, by reason of physical force exercised through its official agents, execute on every foot of American soil the powers and functions which belong to it. The same comprehension enabled President Cleveland, in response to the impudent demand of Governor 
Altgeld, to reply with grim earnestness that the United States would protect with its troops the mails of the United States against unlawful obstruction in the city of Chicago.

It enabled Justice Brewer, in the Debs Case, to demonstrate that the courts of the United States have also power to remove or restrain such obstructions, and to punish disobedience of its orders.

Now, gentlemen, just look at that triple set of decisions which came either from the Supreme Court, or from the Attorney-General, and President Cleveland. The first, that the United States could, by its marshals and its peace officers, carry out upon every foot of soil the laws of the United States; the second, that it could use its troops to protect the property of the United States; and the third, that its courts would see to it that the functions of the United States were not to be suppressed or restrained by anarchistic force, or any other kind of force.

Any weaker construction of the powers of the government would have resulted in the triumph of anarchy; and John Marshall, plain of speech and modest of manner, wrote for all time, upon a half-dozen quires of foolscap paper, the principles which, as it has been said, made us a nation. And I trust if I should go on a little further and use the word which the statistical accuracy of Judge Baldwin has said has been used about two thousand times in this country in the past eighteen months, use the word "Empire," I trust that no cold chills or symptoms of grippe would appear.

And now, a word or two, gentlemen, about the personnel and the humanities of the man. Until twenty-five years ago, it was the custom in this circuit for the presiding judge of the Circuit Court to read, at the beginning of the term, the opinions in undecided cases; and one of my predecessors was wont to write with care and deliver with appropriate earnestness elaborate opinions, especially in patent cases. He was thus delivering one day, before a full court-room, an opinion which bombarded from various points, and defended also, an important patent, when he paused for a rest, and incidentally for refreshment from his tobacco-box. A lawyer near him, who had been intently watching the different phases of the opinion, declared in a very audible whisper, with more fervency than piety, "Well, he is human."

There never was doubt of the humanity of John Marshall. Biographers unite in asserting that he was tall and meagre, 
with a figure illy adapted to the art of the tailor; that he was plain in manner, with some carelessness in dress, a sunny and cheerful disregard of exclusiveness, and a willing leader in the simple athletic sports of the day. He had not the New England mechanical aptitude and readiness to meet ordinary emergencies. I do not suppose that he could skillfully put down a carpet or put up a chimney-pipe, and he is even said to have been indolent in study. He was the embodiment of patience and courtesy in court, and listened with a conscientious fidelity, and with a winning manner which dispelled youthful self-distrust.

His kindness of heart was as manifest as was his modesty and his affection for those dependent upon him was unbounded, while the earnestness of his convictions gleams out once in a while amid his ordinary unimpassioned argument. With this combination of qualities, which attracts cordial good-will, it is not strange that in political life he was always a popular candidate and a universal favorite.

But how was he personally regarded by the lawyers over whom he presided? It is a fact that one of the mishaps in the life of a judge consists in the relaxation, and relaxation is not quite the word I want, but in the interruption of the enjoyment of the old and familiar friendships of the Bar. The lawyers go out of one door; the judge disappears from another door, and goes into his chamber alone, to turn over the results of the day, or to look forward with philosophical indifference to what is coming, as his mood may be. The lawyers have perhaps gone, in Judge Martin Grover's well-known analysis of litigation, to the tavern to swear at the Court; but wherever Court and Bar may be they are necessarily separated. None of this isolation came to Judge Marshall; he was beloved by the Bar with a personal love, exhibited in such a clear and unpremeditated way that a blind man could have perceived it.

In the great cases with which Judge Marshall's name is particularly associated the Court was a unit. In one instance to which allusion has been made by the President of the Bar, the case of Ogden Y. Saunders, upon the effect of a State statute of insolvency, he dissented from the views of the majority of the Court, a dissent in which he is said to have had the concurrence of Mr. Webster's subsequent deliberate judgment.

I recollect that the late Professor Phelps said, after the death of an old and distinguished judge, that he will be best 
known hereafter by the strength and wisdom of his dissenting opinions; and I am moved by the professor's suggestion to say, that in the final outcome of judgment upon a lawyer's life, the question of prime importance is, not, did he gain his cases, but, was he right? And that likewise the question of prime importance upon a 'judge's life is, not, was he overruled, but, was he right?

The ultimate aim at which we are all striving is the truth, for truth is eternal and success is temporal. A lawyer must admit that the search in his profession is not, like that of a clergyman, after the noblest, highest verities which belong to man's spiritual nature; it is for the highest attainment in the relation of nations to each other, and in the ethics which govern human conduct and society; but we are in search of the truth, the truth which was revealed from time to time to Judge Marshall by an almost instantaneous clearness of vision. It may be found by us after a more prolonged search, during which it is veiled for a time, but the object of us all, students and lawyers, whether judges or in other stations, is the same, to find the truth and proclaim rightness. In that quest, gentlemen, we have paused to-day to pay tribute to the greatest leader of American lawyers, John Marshall. [Applause.]

\section{DEAN WAYLAND.}

This being a purely secular occasion we shall dispense with the benediction; but as a poor substitute for that we wish to invite you to an inspection of the building, which some of you have never seen, and very many of you have never seen entirely. After inspection we invite you to a simple refection in the room above. The audience is now dismissed. 